\title{
Effect of tidal overwash on the embryonic development of leatherback turtles in French Guiana
}

\author{
Stéphane Caut ${ }^{\mathrm{a}, *, 1}$, Elodie Guirlet ${ }^{\mathrm{b}, 1}$, Marc Girondot $^{\mathrm{c}}$ \\ ${ }^{a}$ Doñana Biological Station, Avda. Maria luisa S/n, 41013 Seville, Spain \\ b Laboratory for Oceanology, MARE Centre, University of Liège, allée de la Chimie 17, B6C, 4000 Liège (Sart-Tilman), Belgium \\ 'Laboratory of Ecology, Systematic and Evolution, UMR 8079, CNRS, University of Paris-Sud, Orsay 91405, France
}

\section{A R T I C L E I N F O}

\section{Article history:}

Received 12 June 2009

Received in revised form 2 November 2009

Accepted 6 November 2009

\section{Keywords:}

Tidal inundation

Leatherback turtle

Embryonic mortality

French Guiana

Development

Site selection

\begin{abstract}
A B S T R A C T
In marine turtles, the physical conditions experienced by eggs during incubation affect embryonic development. In the leatherback, hatching success is known to be low in relation to other marine turtles as a result of high embryonic mortality. Moreover, the hatching success on Yalimapo in French Guiana, one major nesting beach for this species, is lower compared to other nesting sites. We assessed the rate of leatherback turtle embryonic mortality in order to investigate the tolerance of leatherback turtle clutches laid on Yalimapo beach to tidal overwash, and we highlight causes of poor hatching success. Of the 89 nests studied, 27 were overlapped by tide at least once during the incubation period (of which five nests were lost by erosion). The hatching success was on average significantly lower in overwashed nests than in non-overwashed, highlighting the existence of embryonic developmental arrest linked to tidal inundation. The stages of developmental arrest and their proportion are linked with time, frequency and level of overwash events. In the context of global warming and associated sea-level rise, understanding the detrimental effect of tidal inundation on the development of marine turtle nests is of interest in nesting sites where turtles are likely to be forced to nest closer to the tide line, thus exposing their nests to greater risk of nest overlap with sea and tidal inundation.
\end{abstract}

(c) 2009 Elsevier Ltd. All rights reserved.

\section{Introduction}

For animals that lay their eggs in a nest, the selection of a nest site may strongly influence embryo development and offspring survival and may therefore have important consequences for the reproductive fitness of the adult. Indeed, for most oviparous species, the most vulnerable part of the life cycle is often the embryo stage, since eggs are typically left in fixed locations throughout their development without parental care (Wood and Bjorndal, 2000). Hatching success for organisms that lay eggs in a nest, such as sea turtles, is believed to be influenced by numerous biotic and abiotic factors such as predation, type of substrate, porosity, temperature, moisture content, salinity, slope of the beach, nest elevation, rainfall and tidal inundation (Mortimer, 1990; Horrocks and Scott, 1991; Ackerman, 1997; Wood and Bjorndal, 2000; Allen et al., 2001; Bilinski et al., 2001; Donlan et al., 2004; Foley et al., 2006). In many oviparous reptiles, however, environmental factors not only influence embryo survivorship (Horrocks and Scott, 1991; Resetarits, 1996), but also hatchling size (Packard and Packard, 1988), performance (Janzen, 1993), growth (Bobyn and Brooks,

\footnotetext{
* Corresponding author. Tel.: +34 954466700x1316; fax: +34954 621125 . E-mail address: stephanecaut@gmail.com (S. Caut).

${ }^{1}$ Both authors contributed equally to this study.
}

1994), behaviour (Burger, 1991), and sex determination (Spotila et al., 1994). After the emergence of hatchling turtles, their survival may be strongly related to the distance at which the nest is laid from the sea and from supra-littoral vegetation behind the beach (Mrosovsky, 1983). Placement of nests close to the sea increases the likelihood of inundation and egg loss to erosion, whereas placement of nests farther inland increases the likelihood of desiccation, hatchling misorientation, and predation on nesting females, eggs, and hatchlings (Bustard and Greenham, 1968; Fowler, 1979; Whitmore and Dutton, 1985; Spencer, 2002).

Leatherback turtles (Dermochelys coriacea), classified as critically endangered by the Species Survival Commission (IUCN, 2006), often place their nests in the open sand near the water, but rarely in vegetation (Whitmore and Dutton, 1985; Kamel and Mrosovsky, 2004; Caut et al., 2006a). For this reason, researchers have investigated possible strategies and cues that might influence nest placement. Mrosovsky (1983), at the population level, and Eckert (1987), at the individual level, suggested that leatherbacks have developed a scatter nesting strategy whereby nests are randomly distributed along a beach to maximize clutch survival in an unpredictable nesting area. However, leatherback turtles often nest in places where their eggs are destroyed by high tides. Poor nest-site selection, where nests have been shown to completely fail, ranges from $<2.5 \%$ in Malaysia to around $40 \%$ in the Guianas 
and appears to be related to beach topography (Mrosovsky, 1983). Leatherbacks generally have low hatching success ( $\sim 50 \%)$ relative to other marine turtle species ( $\sim 85 \%$ or more; see Bell et al., 2004). Predation could partly explain the low hatching rate, with the longer incubation period for leatherbacks increasing exposure to predators (Whitmore and Dutton, 1985). But this low hatching success of leatherbacks also seems to be mainly the result of nest-site selection and embryonic mortality (Whitmore and Dutton, 1985; Bell et al., 2004). Indeed, leatherbacks generally nest nearer to the sea than other marine turtles and nests are therefore subjected to erosion and inundation, sometimes leading to $50 \%$ nest loss on certain beaches in South America (Patino-Martinez et al., 2008). These overwashes of nests by sea water may lead to egg mortality from suffocation (lack of respiratory oxygen; Whitmore and Dutton, 1985) and/or disruption of metabolism as a result of exposure to higher salinities and therefore chloride toxicity (Bustard and Greenham, 1968) and/or critical cooling below minimum temperature for embryonic development (Hewavisenthi and Parmenter, 2002). Moreover, leatherback nests are deeper than those of others marine turtles, and water content and salinity are known to increase with depth, leading to a decrease in hatching success (Foley et al., 2006). The greater embryonic mortality in leatherback nests is therefore mainly due to the nest-site selection resulting in more nests being overwashed.

However, the effect of tidal overwash on hatching success and embryonic development remains poorly understood and represents an important question for the future. Indeed, threats to coastal areas are increasing (Huang, 1997) with the projected rise in sea level resulting from anthropogenic global warming; the increase in the number and concentration of greenhouse gases in the atmosphere has the potential to cause an elevation in the global mean air temperature and mean sea level of $1-4.5^{\circ} \mathrm{C}$ and $31-150 \mathrm{~cm}$, respectively, by the year 2100 (IPCC, 2007). Therefore, many nesting beaches are particularly susceptible to coastal hazards such as storm surges and coastal erosion. However, although much effort has been expended over the last two decades to understand and mitigate the threats to marine turtles (Watson et al., 2005), the threat of climate change on this taxon has, until recently, been given little attention (for more information, see Hawkes et al., 2009). Studies of the effects of global warming on sea turtle populations have focused essentially on the loss of nesting beach habitat as a result of an increase in sea level and on the changes in sex ratio (Daniels et al., 1993; Davenport, 1997; Nicholls, 1998; Nicholls et al., 1999; Fish et al., 2005, 2008; Baker et al., 2006; Jones et al., 2007; Mazaris et al., 2009). Most of these studies examined the potential effect of sea-level rise on marine turtle nesting beaches with different models (e.g. elevation model, inundation flooding model), but they did not take into account how life history and ecological parameters that determine extinction risks will be affected by climate change (Isaac, 2009). The recent review on climate change and marine turtles (Hawkes et al., 2009) therefore indicated the importance for future research on climate change effects on key habitats upon which turtles depend and factors that influence nest-site selection and hatchling success. The effect of inundation and, indirectly, the sea-level rise on leatherback hatching success have been poorly studied (Whitmore and Dutton, 1985) to date, despite the tendency of this species to lay its clutches closer to the high-tide line than other sea turtle species. Results of studies concerning global warming have highlighted threats for coastal zones with accelerated beach erosion and greater frequency of flooding events (Kumar, 2006).

The beach of Yalimapo has one of the highest nesting densities of leatherback females, with about $30 \%$ of the world's population of nesting females and approximately $50 \%$ of all leatherbacks nesting in the region of French Guiana and Suriname (Girondot and Fretey, 1996), it should be noted that the exact proportion varies accord- ing to the year. However, hatching success on this beach is lower than at other leatherback nesting sites (Boulon et al., 1996). Depressed hatching success compounds the problem of population decline that results from adult mortality caused by incidental fisheries capture (Kaplan, 2005; Martinez et al., 2007), and understanding the causes of low hatching success would therefore be an important conservation step towards preventing extinction in a species (Ralph et al., 2005). In this study, we determined the level and frequency of tidal overwash and hatching success of leatherback nests in order to investigate the tolerance of nests to tidal inundation in the context of global warming and sea-level rise. We assessed the rate and stages of leatherback turtle embryonic mortality in order to investigate tolerance of leatherback turtle clutches laid on Yalimapo beach to tidal overwash and we highlight causes of poor hatching success.

\section{Materials and methods}

\subsection{Study site and data collection}

Research was carried out on the Awala Yalimapo beach in French Guiana $\left(53^{\circ} 57^{\prime} \mathrm{W}-5^{\circ} 45^{\prime} \mathrm{N}\right)$. The beach is located within the Amana Nature Reserve, on the inshore plain of coastline between the Mana and Maroni Rivers. Guyana has a semi-diurnal tide (two daily high tides) with a period of approximately 12-and-a half hours. The beach is $4 \mathrm{~km}$ in length and the width varies from a few metres to $20 \mathrm{~m}$, depending on the tide line. For this study, we chose a 300-m long section of beach with the same slope (approximately $10 \%)$, which was sufficiently frequented by turtles but also distant from sites frequented by tourists. The width of the sand beach depends on the strength of the tide $(\sim 5-30 \mathrm{~m})$.

The nests analysed in the study were laid from 20 May to 4 June 2002. At the time of oviposition or later, during nest covering, we measured the minimum straight carapace length of the nesting female (SCLmin) (Bolten, 1999) and the female identity was recorded (Passive Integrated Transponder (PIT) tags). For each freshly laid nest encountered, we measured the minimum distance from the nest to the last high-tide line and to the vegetation line (sparse creeping vegetation (Ipomoea pes-caprae), sand still visible) with a plastic measuring tape. All nest locations were localized to within $1 \mathrm{~m}$ by triangulation using numbered stakes placed every $10 \mathrm{~m}$ along the vegetation of the beach. To locate specific nests after incubation, we placed a numbered ring of plastic-insulated copper in the sand above the clutch during the covering of the nest by the female. We used a metal detector that captured signals from probes in the copper at the end of incubation.

\subsection{Embryonic development}

Nest status was checked each day for signs of emergence, predation by dogs or erosion. We waited sufficient time for any live embryos to hatch and leave the nest before analysing the remaining embryos. All nests were excavated $48 \mathrm{~h}$ after the first signs of emergence; in the absence of evidence, we expected a period of 70 days of incubation, so no live embryos were excavated or sacrificed (authorization No. 1516 1D/1B/ENV of 27 August 2001, DIREN Guyane). We recorded the total number of yolked eggs (noted YE, including hatched and unhatched yolked eggs) and shelled albumin globs (noted 'yolkless' eggs). We dissected unhatched yolked eggs in situ and staged them in category using these criteria:

- Category 1: egg with no visible signs of development or dead embryo $<10 \mathrm{~mm}$ in length.

- Category 2: egg with dead embryo $\geqslant 10 \mathrm{~mm}$ and $<30 \mathrm{~mm}$ in length. 
- Category 3: egg with dead embryo $\geqslant 30 \mathrm{~mm}$ and $<60 \mathrm{~mm}$ in length.

- Category 4: egg with dead embryo $\geqslant 60 \mathrm{~mm}$ (including dead hatchling in a pipped egg).

\subsection{Embryonic size and time of incubation}

To analyse the effect of tidal overwash on embryonic development, we determined for each category of embryonic size a corresponding time of incubation. Renous et al. (1989) presented a stage-by-stage description of leatherback development and reported that many measurements of embryonic growth could be related to developmental time (incubation period). We used Renous' stage description to estimate rates of growth. These growth curves were performed by Renous et al. (1989) on the same beach (Awala Yalimapo, French Guiana) with a random sampling of nests in natural environment and between the end of May and the beginning of August. We fitted these data using an exponential function: $y=2.85 \exp (0.05 x) R^{2}=0.99$, with the embryonic size on the $y$ axis ( $\mathrm{mm}$, with maximum $110 \mathrm{~mm}$ ) and the time of incubation on the $x$ axis. We determined the incubation period for each size class of each category:

Category 1 corresponded to the period ${ }^{1} 0-23$ days; Category 2 to the period ${ }^{2} 24-43$ days; Category 3 to the period ${ }^{3} 44-56$ days; Category 4 to the period ${ }^{4}$ 57-67 days.

\subsection{Percentage of embryos and hatchling success}

We estimated the percentage of embryos for each category $(p(E))$ as:

$p\left(E_{n}\right)=E_{n} / Y E$,

where $n=$ the category $1-4 ; E=$ number of embryos in the category $n ; Y E=$ total number of yolked eggs.

We also estimated the percentage of embryos for categories 2-4 of the total yolked eggs that can continue their development at each corresponding period $(\mathrm{pc}(E))$ as:

$$
\begin{aligned}
& \operatorname{pc}\left(E_{2}\right)=E_{2} /\left(Y E-E_{1}\right) \\
& \operatorname{pc}\left(E_{3}\right)=E_{3} /\left(Y E-E_{1}-E_{2}\right) \\
& \operatorname{pc}\left(E_{4}\right)=E_{4} /\left(Y E-E_{1}-E_{2}-E_{3}\right)
\end{aligned}
$$

Hatching success was estimated by the number of large shell fragments divided by the total number of yolked eggs. When eggshells were fragmented, pieces were grouped together to represent one egg. The use of shell fragments to estimate hatching success had been previously validated in an open-air hatchery study (Caut et al., 2006b).

\subsection{Measurements of overwash}

During each day of incubation time, we measured the minimum distance from each nest to the daily high-tide line (represented by the high-water mark of the two daily highs, noted DDHTL (Daily Distance to the High-Tide Line; "+" positive for distance non-overwash and "-" negative for distance overwash), see Fig. 1). To define the characteristics of overwash for each of the four specific periods (period $^{1}$ : 0-23 days, period ${ }^{2}$ : 24-43 days, period ${ }^{3}$ : 44-56 days, and period ${ }^{4}$ : 57-67 days), we define four different parameters (see Fig. 1):

- The Total Distance (TD): corresponding to the sum of DDHTL (positive or negative), the total overwash history of nest for one period.

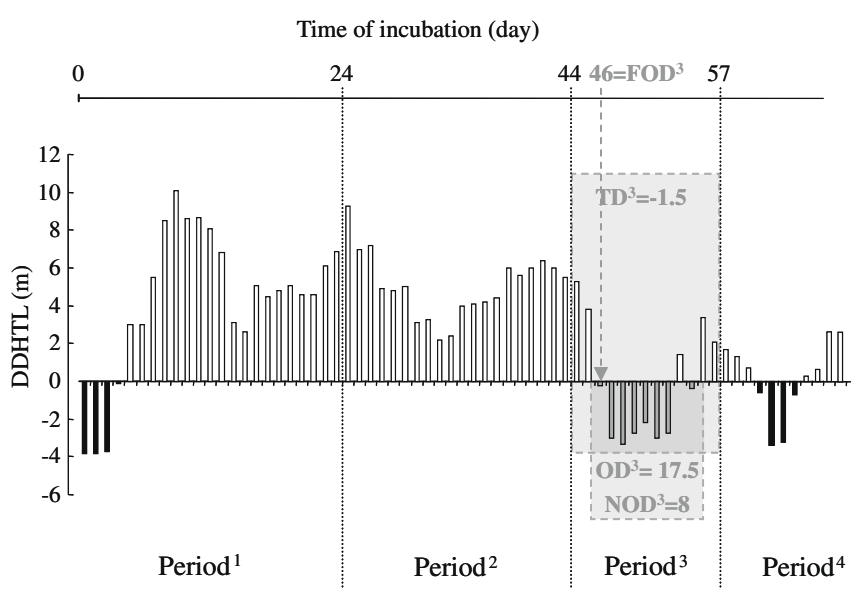

Fig. 1. Example of overwashed pattern in one nest during the 67 days of the study. Daily Distances of the High-Tide Line (DDHTL) to the nest are shown. Negative distance represents overwashed events and is highlighted in black. The four periods were represented and for period ${ }^{3}$, we have represented and calculated the different measurements of overwash for one nest to illustrate: Total Distance (TD) Overwashed Distance (OD), Number of Overwashed Day (NOD) and First Overwashed Day (FOD). (For information this nest has a hatching success $=0 \%$, with $p E_{1}=100 \%$.)

- Overwashed Distance (OD): the absolute value of the sum of daily distances, in metres, between the nest and the high-tide line for overwashed days (negative values in Fig. 1), index of the level of tidal overwash.

- The Number of Overwashed Day (NOD): the sum of overwashed days, index of the frequency of tidal overwash.

- The First Overwashed Day (FOD): the first day of the incubation for which an overwash was recorded for each specific period.

\subsection{Statistical analysis}

As all females laid only one clutch during the study period, they could be treated independently in the analysis. We decided to eliminate nests laid in vegetation and nests depredated prior to a completed period (about 67 days). First, we performed one-way ANOVAs using either SCLmin, the number of yolked eggs or the number of yolkless eggs as the dependent variable, and the state of nest (overwashed or non-overwashed) was treated as the independent variable. Generalized linear models (GLM) were also performed to assess the effect of overwash on (1) hatching success and (2) percentage of dead embryos (corrected or not) in the different categories 1-4. Nests were considered as overwashed when they were covered by tide at least once during the incubation time. Second, GLM were performed to assess the effect of $T D$ of each different period on the corrected percentage of corresponding dead embryos for overwashed and non-overwashed nests. Finally, GLM were performed among overwashed nests to investigate variables responsible for developmental arrest through incubation periods $(O D, F O D, N O D)$. Preliminary analysis was carried out to estimate the correlation between $O D$ and NOD; if this correlation was significant, we selected only $O D$ for the GLM. One model with first-order interactions was fitted for each period and corresponding embryonic category $n$ :

$G^{n}\left(\mathrm{pc} E_{n}\right)=O D^{n}+F O D^{n}+N O D^{n}+$ error

where $G$ is a link function and $n$ corresponds to one period as defined above. $O D, F O D$ and NOD were treated as continuous independent variables. As dependent variables were percentages $\left(\mathrm{pc} E_{n}\right)$, we used binomial error distribution and logit link function. Computations were performed with the SAS package (procedure MIXED, v. 9.1.3, SAS Institute Inc., 2004). 


\section{Results}

Over a period of 15 days, we marked and followed 97 nests along a $300 \mathrm{~m}$ stretch of beach. At the end of the study, five nests were lost by erosion, six nests by dog predation and two nests by human poaching. Of the remaining 84 nests, 22 had been overwashed at least once, 55 nests were non-overwashed and seven were nested in vegetation. Therefore, the remaining 77 nests were analysed for hatching success and the effect of overwash on embryonic mortality assessed.

\subsection{Hatching success and embryonic mortality}

First, we tested whether there were significant differences between the characteristics of females (SCLmin) and clutch size for overwashed and non-overwashed nests. We found no difference between the general characteristics in these two categories; the SCLmin and the number of yolked and yolkless eggs were very similar (Table 1A).
However, the hatching success and the percentage of total dead embryos were significantly different between nests that were overwashed or not (Table 1A). Hatching success was significantly smaller for nests that were overwashed. The percentage of total dead embryos was significantly higher in overwashed nests (Table 1A).

\subsection{Embryonic arrest vs. time of overwash}

We calculated the percentage of nests with dead embryos for each size of embryo for overwashed and non-overwashed nests and we compared this with the percentages of overwashed nests for each day of incubation (Fig. 2). We observed different patterns of embryo distribution:

- Period ${ }^{1}$ between 0 and 23 days (corresponding to an embryo size of $<10 \mathrm{~mm}$ ) in which there was the same frequency of occurrence for the overwashed and non-overwashed nests, approximately $100 \%$, meaning that all nests had embryos

Table 1

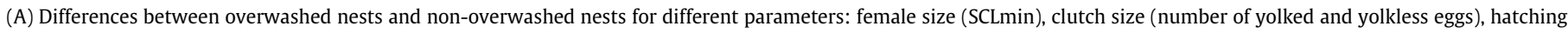

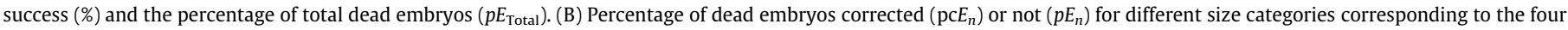
different periods. A nest was considered overwashed when it was overwashed during the period corresponding to the embryonic size.

\begin{tabular}{|c|c|c|c|c|c|c|c|c|c|}
\hline & & \multicolumn{3}{|c|}{ Overwashed nests } & \multicolumn{5}{|c|}{ Non-overwashed nests } \\
\hline & & Mean & $\mathrm{SD}$ & $n$ & Mean & SD & $n$ & $F / \chi^{2}$ & $P$ \\
\hline \multicolumn{10}{|c|}{$A$} \\
\hline & SCLmin & 161.8 & 8.3 & 22 & 161.7 & 8.0 & 55 & $<0.01$ & 0.958 \\
\hline & Number of yolked eggs & 90.3 & 21.0 & 22 & 86.9 & 21.7 & 55 & 0.39 & 0.534 \\
\hline & Number of yolkless eggs & 21.9 & 8.1 & 22 & 25.0 & 10.2 & 55 & 1.64 & 0.204 \\
\hline & Hatching success & 28.3 & 26.8 & 22 & 44.9 & 17.9 & 55 & 168.42 & $<0.001$ \\
\hline & $p E_{\text {Total }}$ & 54.5 & 32.1 & 22 & 33.2 & 17.1 & 55 & 263.75 & $<0.001$ \\
\hline \multicolumn{10}{|c|}{$B$} \\
\hline & $p E_{1}$ & 50.3 & 31.0 & 15 & 29.7 & 16.9 & 62 & 166.69 & $<0.001$ \\
\hline & $p E_{3}$ & 2.0 & 3.5 & 14 & 0.4 & 2.1 & 63 & 29.57 & $<0.001$ \\
\hline & $\mathrm{pc} E_{3}$ & 3.8 & 7.3 & 13 & 1.0 & 4.6 & 62 & 42.30 & $<0.001$ \\
\hline & $p E_{4}$ & 11.9 & 16.7 & 16 & 2.8 & 2.7 & 61 & 184.65 & $<0.001$ \\
\hline & $\mathrm{pc} E_{4}$ & 25.9 & 29.2 & 16 & 4.2 & 4.0 & 59 & 238.57 & $<0.001$ \\
\hline
\end{tabular}

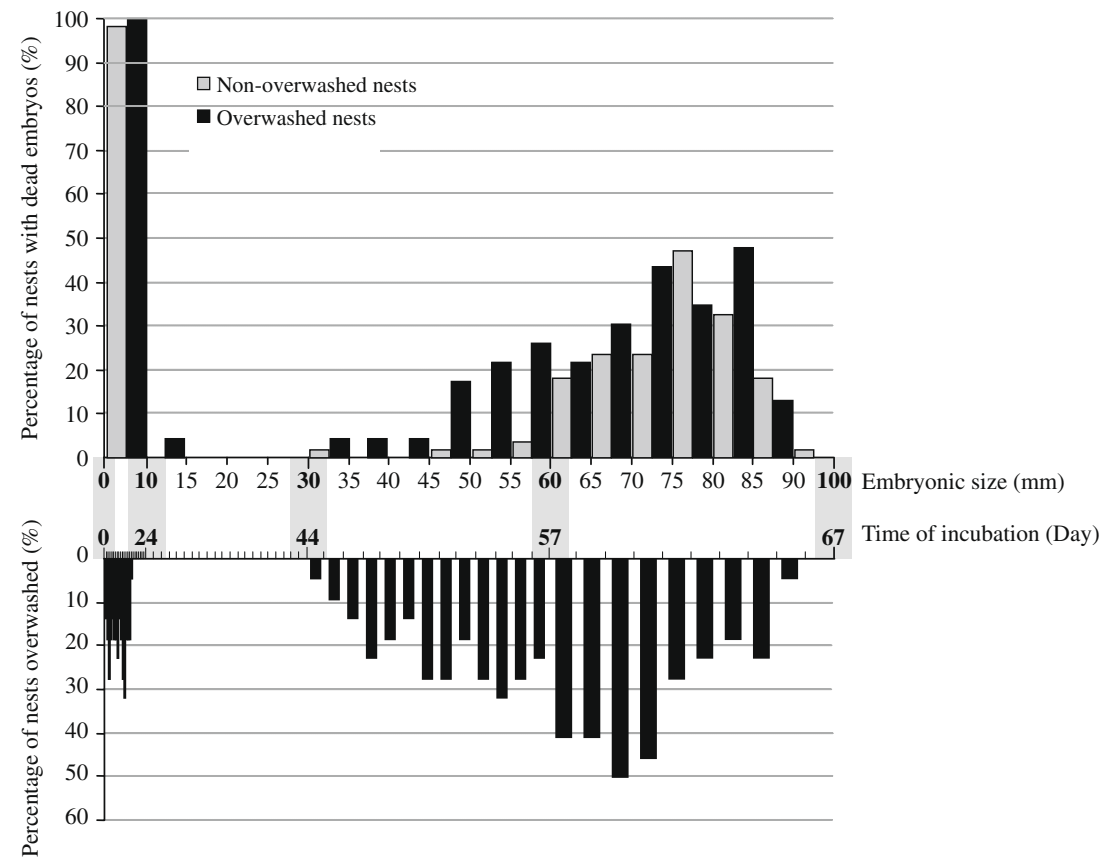

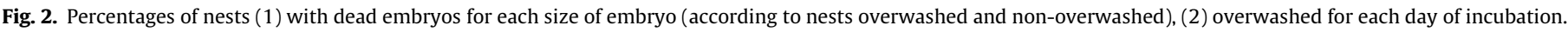
The $x$ axis shows both embryonic size and corresponding time of incubation. 
Table 2

Variations of the corrected percentage of dead embryos during period ${ }^{1}$ ( $0-23$ days) and period ${ }^{4}$ (57-67 days). (A) Effect of TD (Total Distance) of each different period on the corrected percentage of corresponding dead embryos for overwashed and nonoverwashed nests. (B) Effect of $O D$ (Overwashed Distance) and FOD (First Overwashed Day) of each different period on the corrected percentage of corresponding dead embryos for overwashed nests.

\begin{tabular}{|c|c|c|c|c|c|c|}
\hline & \multirow[t]{2}{*}{ Variables } & \multirow[t]{2}{*}{ Predictors } & \multicolumn{2}{|c|}{ Overwashed nests } & \multicolumn{2}{|c|}{ Non-overwashed nests } \\
\hline & & & $\chi^{2}$ & $P$ & $\chi^{2}$ & $P$ \\
\hline \multicolumn{7}{|c|}{$A$} \\
\hline & $\mathrm{pc} E_{1}$ & $T D^{1}$ & 224.35 & $<0.001$ & 1.77 & 0.184 \\
\hline & $\mathrm{pc} E_{4}$ & $T D^{4}$ & 167.47 & $<0.001$ & 0.54 & 0.462 \\
\hline \multicolumn{7}{|c|}{$B$} \\
\hline & $\mathrm{pc} E_{1}$ & $O D^{1}$ & 126.29 & $<0.001$ & & \\
\hline & & $F O D^{1}$ & 97.22 & $<0.001$ & & \\
\hline & $\mathrm{pc} E_{4}$ & $O D^{1}$ & 134.70 & $<0.001$ & & \\
\hline & & $F O D^{1}$ & 0.59 & 0.4440 & & \\
\hline
\end{tabular}

of $<10 \mathrm{~mm}$. However, the percentage of dead embryos of $<10 \mathrm{~mm}$ was significantly different between nests that were overwashed or not ( $50.32 \%$ and $29.73 \%$, respectively, Table $1 \mathrm{~B}$ ). During this period, the overwashed nests were frequently overwashed during the 16 first days.

- Period ${ }^{2}$ between 24 and 43 days (corresponding to an embryo size of $10-30 \mathrm{~mm}$ ) in which there was only one embryo. This was probably due to the fact that we had no nests overwashed between the times of incubation.

- Period $^{3}$ between 44 days and 56 days (corresponding to an embryo size of $30-60 \mathrm{~mm}$ ), in which there was a majority of embryos from overwashed nests. During this period 15/22 nests were inundated. As tidal overwash began to occur in nests (day 44 ), the percentage of nests with dead embryos began to increase (Fig. 2). The percentage of dead embryos 30-60 mm (corrected or not) was significantly different between nests that were overwashed or not (Table $1 \mathrm{~B}$ ).

- Period ${ }^{4}$ between 57 and 67 days (corresponding to an embryo size $>60 \mathrm{~mm}$ ), in which we observed an important percentage of nests with dead embryos from overwashed and non-overwashed nests. However, the percentage of dead embryos of $>60 \mathrm{~mm}$ was significantly different between overwashed and non-overwashed nests (pc $E_{4}: 25.87 \%$ and $4.21 \%$, respectively, Table 1B). During this period 15/22 nests were overwashed.

\subsection{Sensitivity of embryos vs. parameters of overwash}

To study more precisely the effect of overwash on embryonic mortality, we selected three different periods corresponding to the presence of embryo size: period ${ }^{1}$ (1-24 days), period ${ }^{3}$ (4456 days) and period ${ }^{4}$ (57-67 days). First, we performed GLM to assess the general effect of $T D$ (sum of daily distance to the high-tide line) during two periods (period ${ }^{1}$ and period ${ }^{4}$ ) on the percentage of corresponding dead embryos $\left(\mathrm{pc} E_{n}\right)$ for overwashed and non-overwashed nests (Table 2A). We did not perform GLM for period ${ }^{2}$ (no overwash) or for period ${ }^{3}$, because the $T D$ and the number of dead embryos were very low (Fig. 3). For the two periods (1 and 4), TD was found to be significant for overwashed nests and not significant for non-overwashed nest (Table 2A). The percentage of dead embryos increased with $T D$. Second, GLM were performed among overwashed nests to investigate more precisely variables responsible for embryonic arrest $(O D, F O D, N O D)$. Preliminary analysis found a significant correlation between $O D$ and NOD $(R=0.87)$. We selected therefore only OD for the GLM $\left(G^{1}\left(\mathrm{pc} E_{1}\right)=O D^{1}+F O\right.$ $D^{1}+$ error and $G^{4}\left(\mathrm{pc} E_{4}\right)=O D^{4}+F O D^{4}+$ error for period ${ }^{1}$ and peri$\mathrm{od}^{4}$, respectively). The GLM model for period ${ }^{1}: O D^{1}$ and $F O D^{1}$ was significant (Table $2 \mathrm{~B}$ ). The percentage of embryos $E_{<10}$ increased
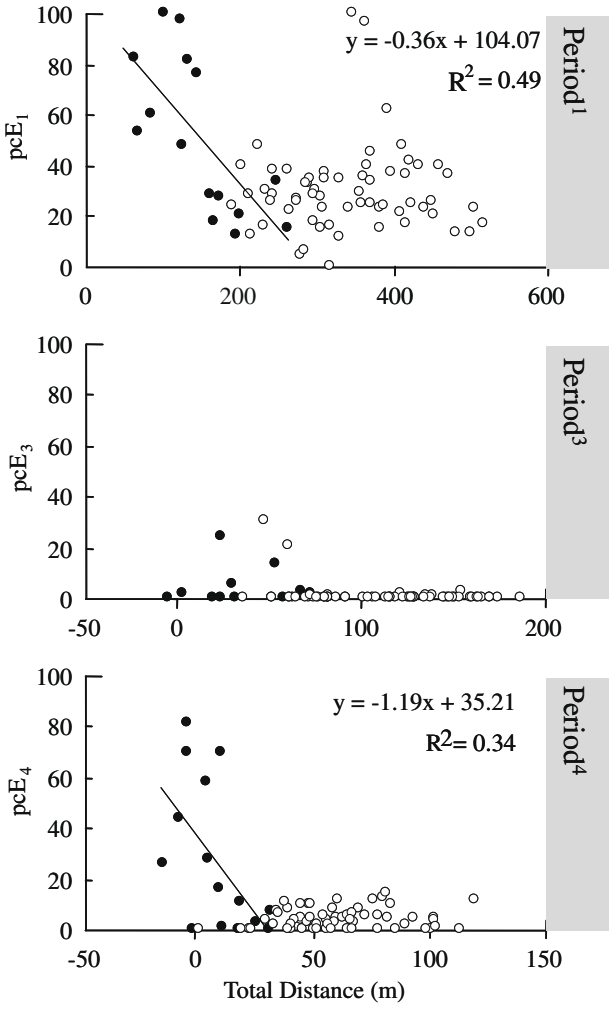

Fig. 3. Relationships between percentage of embryos corrected $\left(\mathrm{pc} E_{n}\right)$ and the Total Distance $(T D)$ of the nest to the tide line on the Yalimapo beach. Overwashed nests are represented with black circles and non-overwashed nests with white ones. Only significant regressions are represented.

with $O D^{1}$ and when the $F O D^{1}$ decreased (the earlier the nest was overwashed, the more abundant were the dead embryos). The GLM model for period ${ }^{4}$ : Only $O D^{4}$ was found to be significant. The percentage of embryos $\mathrm{E}_{>60}$ increased with $O D^{4}$. The non-significance of $F O D^{4}$ was probably due to the short duration of this period (Table 2B).

\section{Discussion}

In marine turtles, the physical conditions experienced by the egg during incubation in the nest have been shown to strongly affect embryonic development and hatching rate (Mortimer, 1990; Ackerman, 1997; Marco et al., 2005). As female marine turtles do not provide parental care to eggs or offspring, female nesting behaviour and nest-site selection are important factors that can largely affect the development of embryos and the survival of juveniles (Kamel and Mrosovsky, 2004). Our results showed first that many nests were inundated at least once during the incubation periods and that these nests were not automatically associated with null hatching success, but presented a higher proportion of dead embryos than in non-overwashed nests. This result highlights that overwash may affect important variables for embryonic development leading to embryo mortality. Mortality in our study is probably caused by fluctuations of those important physical or chemical variables for embryo development, caused by overwash, rather than overwash alone. Embryonic mortality (stage and proportion) also seems to be linked with the date of the overwash event during the incubation, the frequency and the level of overwash.

\subsection{Effects of overwash}

The effects of the hydric environment and immersion of the nest during incubation have been studied in reptiles (Losos et al., 
2003) but relatively little attention has been given to those effects in marine turtle. Indeed, Kennett et al. (1998) studied the northern long-necked turtle, Chelodina rugosa, the only reptile known to deposit its eggs underwater (Kennett et al., 1993a). They showed that prolonged immersion of eggs in water results in smaller hatchlings and shorter incubation times, but does not increase egg mortality during incubation. However, other studies have shown that even short-term immersion is fatal for reptilian embryos (Tryonix muticus muticus, Plummer, 1976; Crocodylus porosus, Webb et al., 1977; Alligator mississipiensis, Kushlan and Jacobsen, 1990; Pseudemys nelsoni, Kam, 1994). Embryo death normally results from the influx of water into the egg, with consequent egg swelling and rupture of shell and membranes, but these changes do not occur in C. rugosa eggs (Kennett et al., 1993b). Moreover, for marine species the effect is more important, especially due to the variation in water salinity that may be related to rainfall and tidal inundation. Studies generally concern Caretta caretta or Chelonia mydas in sea turtles (Foley et al., 2006; Mortimer, 1990). The effect of moisture and/or immersion on eggs of leatherback turtles has, for example, been little studied, while their nests are the most likely to be inundated (Whitmore and Dutton, 1985). In our study, immersion of eggs is not necessarily fatal to the whole clutch, thus highlighting that the eggs can withstand flooding episodes. The failure of development during tidal overwash may actually be explained by the fluctuations of the three most important physical variables affecting the survival of reptilian embryos: temperature, water content and respiratory gases (Packard and Packard, 1988). Because leatherbacks nest closer to the tide line than other marine turtles, their nest are more exposed to fluctuations of these important variables. There is an optimal range of temperatures above and below which hatchability decreases. Hatchability is generally known to decrease significantly at lower temperature. The effects of large daily temperature fluctuations on embryonic development are unknown, but prolonged exposure of reptilian eggs below optimum temperature can result in developmental abnormality and embryonic mortality (Packard and Packard, 1988). Moreover, local conditions such as rainfall and tidal overwash may induce pronounced cooling and decrease hatchability if temperature is below minimum temperature for embryonic development (Hewavisenthi and Parmenter, 2002). During overwash, eggs can also be confronted with increased water content and lower gas content, leading to higher moisture and limited or blocked gas exchange responsible for asphyxiation and death of the embryo (Ackerman, 1981; Özdemir et al., 2008). Indeed, the hatching success of loggerhead turtle nests has been shown to decrease when water content increases in this way (Foley et al., 2006). Finally, eggs can be confronted with increased salinity, which is known to reduce the ability of eggs to absorb water (Bustard and Greenham, 1968) and to disrupt cellular metabolism as a result of exposure to higher salinities and therefore chloride toxicity (Bustard and Greenham, 1968).

Mortality during inundation may be related to the stage of development at which inundation occurs. Our results showed a relationship between time of incubation and embryonic arrest. Early and late embryonic stages were identified as the critical periods in the embryonic development of turtles (Whitmore and Dutton, 1985; Girondot et al., 1990; Özdemir et al., 2008). The present study is consistent with these results, since embryonic mortality was higher in both of these stages than during the middle stage. However, there were few inundation events during the middle stages of incubation in our study nests. This study is the first to analyse the daily situation of the nest, and we found a relationship between overwash event and mortality of embryo, with a clear match between days of overwash and embryonic development arrest, judging by the size of dead embryos (see Fig. 2). More research is needed to determine precisely whether the middle stages of incubation are more resilient to the negative impacts of overwash.
Bell et al. (2004) studied the development of leatherback embryos in the laboratory and showed that the early stages appeared to be critical. The late stage seems to be a sensitive period for the development for all nests in general. We found this stage of arrested development in each nest (overwashed or not), although the rate was higher for overwashed nests. This sensitivity appears to result from an increase in gas exchange between the embryo and the nest environment at the end of development (higher metabolism) and a period of immersion at this stage is likely to be more damaging because of higher sensitivity to hypoxia (Thompson, 1993). In addition, we found that mortality during overwash could also be largely dependent on the frequency and the length of overwash. However, overwashed nests in this study also showed high hatching rates, which suggests that nests in marine turtles have a certain tolerance to immersion and can survive a substantial period of time in saltwater. However, if immersion is too long or too frequent, mortality increases drastically. Calcium is another factor linked to inundation which has already been shown to affect development. Calcium is a major component of the eggshell (Ewert et al., 1984; Packard et al., 1984a,b) and is leached from the shell during immersion (Seymour et al., 1997). Eggshell is an important source of calcium for the developing embryo (Packard, 1994), and reduced calcium availability may limit embryonic growth. The loss of calcium also potentially alters eggshell permeability and leads to higher rates of water exchange (water uptake by the yolk and increases in yolk mass and size, Kennett et al., 1998). Finally, when nests were greatly overwashed at the very beginning of the incubation (as in the nest in Fig. 1), hatching success was found to be null with $p E_{1}=100 \%$; this period of immersion is likely to have caused the death of all the eggs. However, it should be noted that yolked eggs with no visible sign of development may not have been fertilized, although results on the population of leatherback along the Guianas (Whitmore and Dutton, 1985) and Costa Rica coasts (Bell et al., 2004) showed a very low rate of infertile yolked egg $\sim 6 \%$.

In our study, only nests that were covered once or more by tide were included in the analysis of the effects of overwash on embryonic development. However, nests that have not been covered by tide might also suffer from the adverse effects of inundation because of immersion due to the water table below the surface of the beach. The water table is the level at which the ground water pressure is equal to atmospheric pressure, and is above the mean sea level (Li et al., 1997). We were unable to assess the height of the water table and it is therefore likely that we underestimated the number of nests affected by the deleterious effects of immersion.

\subsection{Nesting beaches threatened}

Nest placement has major consequences for offspring survival and it is likely that this behaviour is or has been under strong selection (Mrosovsky, 2006). If nest-site selection has a genetic basis, then individual females should be consistent in their particular choice of nesting sites; that is, their choices should be repeatable (Boake, 1989). The significant repeatability of nest-site choice with respect to distance from the high-tide line suggests that this behaviour may show evolutionary potential (Kamel and Mrosovsky, 2004). In this case, it appears that leatherbacks may have the opportunity for further evolution of nest-site choice in response to selection. This is particularly important in the context of current environmental changes and habitat destruction and alteration. Many of these areas are particularly susceptible to coastal hazards such as storm surges and coastal erosion and, with the projected rise in sea level resulting from anthropogenic global warming, threats to coastal areas are increasing (Huang, 1997). Increases in sea-level rise are thought to lead to increases in high-tide levels and the frequency of storm events (Kurle and 
Gudmundson, 2007). Coastal environment and nesting beaches are therefore threatened with more frequent flooding events that are supposed to decrease the viability of the turtles' nests. This threat is especially true for narrow beaches, such as Yalimapo, on which nests are already located close to the high-tide line, thus exposing them to a greater risk of nest overlap and tidal inundation. Reduction of the size of nesting beaches has implications for reproduction success, especially in major nesting sites such as Yalimapo where density-dependent effects have already had a detrimental effect on nest development (Caut et al., 2006b).

However, susceptibility to storm-related threats may vary according to species (Pike and Stiner, 2007); species with lower nest-site fidelity, such as leatherback turtles, would be less vulnerable than those with higher site fidelity (Lahanas et al., 1994; Dutton et al., 1999; Hatase et al., 2002). Moreover, highly dynamic and interseasonally variable nesting beaches in the Guianas (Plaziat and Augustinius, 2004), allow turtles to maintain successful nesting (Kelle et al., 2007), despite the fact that some beaches disappear between nesting years. Such behavioural flexibility may offer opportunities to colonise new beaches, with nesting now occurring at recently formed sites at areas opened after glacial retreats. Whether turtles can colonise nesting areas made available, either thermally or geographically, by climate change remains to be seen (Hawkes et al., 2009). Although it is possible that other beaches in the area could be used, extensive coastal development is occurring regionally, and alternatives are likely to become increasingly scarce. Until a critical habitat can be more clearly identified, it is essential from a conservation standpoint that the choice of beach and new site is not limited because reproductive success could be compromised.

\section{Acknowledgments}

We would like to thank L. Antoni, J. Bernard and S. Quetre for their help in the field, E. Stanek for the design of the probe, E. Angulo for statistical analysis and Matthew Godfrey for his helpful comments on this paper. We wish to thank Jacqueline Minett for improvement of the English. DIREN Guyane provided financial and legal support (1516 1D/1B/ENV of 27 August 2001) and the use of the facilities of the Amana Nature Reserve (Réserve Naturelle de l'Amana).

\section{References}

Ackerman, R.A., 1981. Growth and gas exchange of embryonic sea turtles (Chelonia, Caretta). Copeia, 757-765.

Ackerman, R.A., 1997. The nest environment and the embryonic development of sea turtles. In: Lutz, P.L., Musick, J.A. (Eds.), The Biology of Sea Turtles, vol. 1. CRC Press, pp. 83-106.

Allen, C.R., Forys, E.A., Rice, K.G., Wojcik, D.P., 2001. Effects of fire ants (Hymenoptera: Formicidae) on hatching turtles and prevalence of fire ants on sea turtle nesting beaches in Florida. Florida Entomologist 84, 250-253.

Baker, J.D., Littnan, C.L., Johnston, D.W., 2006. Potential effects of sea level rise on the terrestrial habitats of endangered and endemic megafauna in the Northwestern Hawaiian Islands. Endangered Species Research 2, 21-30.

Bell, B.A., Spotila, J.R., Paladino, F.V., Reina, R.D., 2004. Low reproductive success of leatherback turtles, Dermochelys coriacea, is due to high embryonic mortality. Biological Conservation 115, 131-138.

Bilinski, J.J., Reina, R.D., Spotila, J.R., Paladino, F.V., 2001. The effects of nest environment on calcium mobilization by leatherback turtle embryos (Dermochelys coriacea) during development. Comparative Biochemistry And Physiology A - Molecular \& Integrative Physiology 130, 151-162.

Boake, C.R.B., 1989. Repeatability: its role in evolutionary studies of mating behavior. Evolutionary Ecology 3, 173-182.

Bobyn, M.L., Brooks, R.J., 1994. Interclutch and interpopulation variation in the effects of incubation conditions on sex, survival and growth of hatchling turtles (Chelydra-serpentina). Journal of Zoology 233, 233-257.

Bolten, A.B., 1999. Techniques for measuring sea turtles. In: Eckert L., Bjorndal, K.A., Abreu-Grobois F.A., Donnelly, M. (Eds.), Research and Management Techniques for the Conservation of Sea Turtles, K IUCN/SSC Marine Turtle Specialist Group Publication No. 4, pp. $110-114$.
Boulon, R.H., Dutton, P.H., McDonald, D.L., 1996. Leatherback turtles (Dermochelys coriacea) on St. Croix, US Virgin Islands: fifteen years of conservation. Chelonian Conservation and Biology 2, 141-147.

Burger, J., 1991. Effects of incubation temperature on behavior of hatchling pine snakes - implications for reptilian distribution. Behavioral Ecology and Sociobiology 28, 297-303.

Bustard, H.R., Greenham, P., 1968. Physical and chemical factors affecting hatching in the green turtle, Chelonia mydas (L.). Ecology 49, 269-276.

Caut, S., Guirlet, E., Jouquet, P., Girondot, M., 2006a. Influence of nest location and yolkless eggs on the hatching success of leatherback turtle clutches in French Guiana. Canadian Journal of Zoology 84, 908-915.

Caut, S., Hulin, V., Girondot, M., 2006b. Impact of density-dependent nest destruction on emergence success of Guianan leatherback turtles (Dermochelys coriacea). Animal Conservation 9, 189-197.

Daniels, R.C., White, T.W., Chapman, K.K., 1993. Sea-level rise - destruction of threatened and endangered species habitat in South-Carolina. Environmental Management 17, 373-385.

Davenport, J., 1997. Temperature and the life-history strategies of sea turtles. Journal of Thermal Biology 22, 479-488.

Donlan, E.M., Townsend, J.H., Golden, E.A., 2004. Predation of Caretta caretta (Testudines: Cheloniidae) eggs by larvae of Lanelater sallei (Coleoptera: Elateridae) on Key Biscayne, Florida. Caribbean Journal of Science 40, 415-420.

Dutton, P.H., Bowen, B.W., Owens, D.W., Barragan, A., Davis, S.K., 1999. Global phylogeography of the leatherback turtle (Dermochelys coriacea). Journal of Zoology 248, 397-409.

Eckert, K.L., 1987. Environmental unpredictability and leatherback sea turtle (Dermochelys coriacea) nest loss. Herpetologica 43, 315-323.

Ewert, M.A., Firth, S.J., Nelson, C.E., 1984. Normal and multiple eggshells in batagurine turtles and their implications for dinosaurs and other reptiles. Canadian Journal of Zoology 62, 1834-1841.

Fish, M.R., Cote, I.M., Gill, J.A., Jones, A.P., Renshoff, S., Watkinson, A.R., 2005. Predicting the impact of sea-level rise on Caribbean Sea turtle nesting habitat Conservation Biology 19, 482-491.

Fish, M.R., Cote, I.M., Horrocks, J.A., Mulligan, B., Watkinson, A.R., Jones, A.P., 2008 Construction setback regulations and sea-level rise: mitigating sea turtle nesting beach loss. Ocean \& Coastal Management 51, 330-341.

Foley, A.M., Peck, S.A., Harman, G.R., 2006. Effects of sand characteristics and inundation on the hatching success of loggerhead sea turtle (Caretta caretta) clutches on low-relief mangrove islands in southwest Florida. Chelonian Conservation and Biology 5, 32-41.

Fowler, L.E., 1979. Hatching success and nest predation in the green sea turtle, Chelonia mydas, at Tortuguero, Costa Rica. Ecology 60, 946-955.

Girondot, M., Fretey, J., 1996. Leatherback turtles, Dermochelys coriacea, nesting in French Guiana, 1978-1995. Chelonian Conservation and Biology 2, 204-208.

Girondot, M., Fretey, J., Prouteau, I., Lescure, J., 1990. Hatchling success for Dermochelys coriacea in a French Guiana hatchery. NOAA Technical Memorandum NMFS-SEFC-278, pp. 229-232.

Hatase, H., Kinoshita, M., Bando, T., Kamezaki, N., Sato, K., Matsuzawa, Y., Goto, K. Omuta, K., Nakashima, Y., Takeshita, H., Sakamoto, W., 2002. Population structure of loggerhead turtles, Caretta caretta, nesting in Japan: bottlenecks on the Pacific population. Marine Biology 141, 299-305.

Hawkes, L.A., Broderick, A.C., Godfrey, M.H., Godley, B.J., 2009. Climate change and marine turtles. Endangered Species Research 7, 137-154.

Hewavisenthi, S., Parmenter, C.J., 2002. Incubation environment and nest success of the flatback turtle (Natator depressus) from a natural nesting beach. Copeia, 302-312.

Horrocks, J.A., Scott, N.M., 1991. Nest site location and nest success in the hawksbill turtle Eretmochelys imbricata in Barbados, West-Indies. Marine Ecology Progress Series 69, 1-8.

Huang, J.C.K., 1997. Climate change and integrated coastal management: a challenge for small island nations. Ocean \& Coastal Management 37, 95-107.

IPCC, 2007. Climate change: the physical science basis. In: Solomon, S., Qin, D. Manning, M., Chen, Z., Marquis, M., Averyt, K.B., Tignor, M., Miller, H.L. (Eds.), Contribution of Working Group I to the Fourth Assessment Report of the Intergovernmental Panel on Climate Change. Cambridge University Press, Cambridge, United Kingdom and New York, NY, USA.

Isaac, J.L., 2009. Effects of climate change on life history: implications for extinction risk in mammals. Endangered Species Research 7, 115-123.

IUCN, 2006. 2006 IUCN Red List of Threatened Species.

Janzen, F.J., 1993. An experimental-analysis of natural-selection on body size of hatchling turtles. Ecology 74, 332-341.

Jones, A.R., Gladstone, W., Hacking, N.J., 2007. Australian sandy beach ecosystems and climate change: ecology and management. Australian Journal of Zoology 34, 190-202.

Kam, Y., 1994. Effects of simulated flooding on metabolism and water balance of turtle eggs and embryos. Journal of Herpetology 28, 173-178.

Kamel, S.J., Mrosovsky, N., 2004. Nest site selection in leatherbacks, Dermochelys coriacea: individual patterns and their consequences. Animal Behaviour 68, 357-366.

Kaplan, I.C., 2005. A risk assessment for Pacific leatherback turtles (Dermochelys coriacea). Canadian Journal of Fisheries and Aquatic Sciences 62, 17101719.

Kelle, L., Gratiot, N., Nolibos, I., Therese, J., Wongsopawiro, R., DeThoisy, B., 2007. Monitoring of nesting leatherback turtles (Dermochelys coriacea): contribution of remote-sensing for real time assessment of beach coverage in French Guiana. Chelonian Conservation and Biology 6, 142-149. 
Kennett, R., Christian, K., Pritchard, D., 1993a. Underwater nesting by the tropical freshwater turtle, Chelodina rugosa (Testudinata: Chelidae). Australian Journal of Zoology 41, 47-52.

Kennett, R., Georges, A., Palmer-Allen, M., 1993b. Early developmental arrest during immersion of eggs of a tropical freshwater turtle, Chelodina rugosa (Testudinata: Chelidae), from northern Australia. Australian Journal of Zoology 41, 37-45.

Kennett, R., Christian, K., Bedford, G., 1998. Underwater nesting by the Australian freshwater turtle Chelodina rugosa: effect of prolonged immersion and eggshell thickness on incubation period, egg survivorship, and hatchling size. Canadian Journal of Zoology 76, 1019-1023.

Kumar, P.K.D., 2006. Potential vulnerability implications of sea level rise for the coastal zones of Cochin, southwest coast of India. Environmental Monitoring and Assessment 123, 333-344.

Kurle, C.M., Gudmundson, C.J., 2007. Regional differences in foraging of young-ofthe-year steller sea lions Eumetopias jubatus in Alaska: stable carbon and nitrogen isotope ratios in blood. Marine Ecology Progress Series 342, 303310.

Kushlan, J.A., Jacobsen, T., 1990. Environmental variability and reproductive success of Everglades alligators. Journal of Herpetology 24, 176-184.

Lahanas, P.N., Miyamoto, M.M., Bjorndal, K.A., Bolten, A.B., 1994. Molecular evolution and population genetics of greater Caribbean green turtles (Chelonia mydas) as inferred from mitochondrial-DNA control region sequences. Genetica 94, 57-66.

Li, L., Barry, D.A., Parlange, J.Y., Pattiaratchi, C.B., 1997. Beach water table fluctuations due to wave run-up: capillarity effects. Water Resources Research 33, 935-945.

Losos, J.B., Schoener, T.W., Spiller, D.A., 2003. Effect of immersion in seawater on egg survival in the lizard Anolis sagrei. Oecologia 137, 360-362.

Marco, A., Lopez-Vicente, M.L., Perez-Mellado, V., 2005. Soil acidification negatively affects embryonic development of flexible-shelled lizard eggs. Herpetologica Journal 15, 107-111.

Martinez, L.S., Barragan, A.R., Munoz, D.G., Garcia, N., Huerta, P., Vargas, F., 2007. Conservation and biology of the leatherback turtle in the Mexican Pacific Chelonian Conservation and Biology 6, 70-78.

Mazaris, A.D., Mastinos, G., Pantis, J.D., 2009. Evaluating the impacts of coastal squeeze on sea turtle nesting. Ocean \& Coastal Management 52, 139-145.

Mortimer, J.A., 1990. The influence of beach sand characteristics on the nesting behavior and clutch survival of green turtles. Copeia 3, 802-817.

Mrosovsky, N., 1983. Ecology and nest-site selection of leatherback turtles, Dermochelys coriacea. Biological Conservation 26, 47-56.

Mrosovsky, N., 2006. Distorting gene pools by conservation: assessing the case of doomed turtle eggs. Environmental Management 38, 523-531.

Nicholls, R.J., 1998. Coastal Vulnerability Assessment for Sea Level Rise: Evaluation and Selection of Methodologies for Implementation. Technical Report R098002, Caribbean Planning for Adaption to Global Climate Change (CPACC) Project. $<$ www.cpacc.org>.

Nicholls, R.J. Hoozemans, F.M.J., Marchand, M., 1999. Increasing flood risk and wetland losses due to global sea-level rise: regional and global analyses. Global Environmental Change - Human and Policy Dimensions 9, S69-S87.

Özdemir, A., Türkozan, O., Güçlü, Ö., 2008. Embryonic mortality in loggerhead turtle (Caretta caretta) nests: a comparative study on Fethiye and Göksu delta beaches. Turkish Journal of Zoology 32, 1-6.
Packard, M.J., 1994. Patterns of mobilization and deposition of calcium in embryos of oviparous, amniotic vertebrates. Israel Journal of Zoology 40, 481-492.

Packard, G.C., Packard, M.J., 1988. The physiological ecology of reptilian eggs and embryos. In: Gans, C., Huey, R.B. (Eds.), Biology of Reptilia, Ecology B, Defense and Life History, vol. 16. Alan R. Liss, New York, pp. 523-605.

Packard, M.J., Hirsch, K.F., Iverson, J.B., 1984a. Structure of shells from eggs of kinosternid turtles. Journal of Morphology 181, 9-20.

Packard, M.J., Iverson, J.B., Packard, G.C., 1984b. Morphology and shell formation in eggs and embryons of the turtle Kinosternon flavescens. Journal of Morphology 181, 21-28.

Patino-Martinez, J., Marco, A., Quinones, L., Godley, B., 2008. Globally significant nesting of the leatherback turtle (Dermochelys coriacea) on the Caribbean coast of Colombia and Panama. Biological Conservation 141, 1982-1988.

Pike, D.A., Stiner, J.C., 2007. Sea turtle species vary in their susceptibility to tropical cyclones. Oecologia 153, 471-478.

Plaziat, J.C., Augustinius, P.G.E.F., 2004. Evolution of progradation/erosion along the French Guiana mangrove coast: a comparison of mapped shorelines since the 18th century with Holocene data. Marine Geology 208, 127-143.

Plummer, M., 1976. Some aspects of nesting success in the turtle, Tryonix muticus. Herpetologica 38, 353-359.

Ralph, C.R., Reina, R.D., Wallace, B.P., Sotherland, P.R., Spotila, J.R., Paladino, F.V., 2005. Effect of egg location and respiratory gas concentrations on developmental success in nests of the leatherback turtle, Dermochelys coriacea. Australian Journal of Zoology 53, 289-294.

Renous, S., Rimblot-Baly, F., Fretey, J., Pieau, C., 1989. Caractéristiques de développement embryonnaire de la tortue luth. Dermochelys coriacea (Vandelli, 1761). Annales des sciences naturelles. Zoologie et Biologie Animale 10, 197-229.

Resetarits, W.J., 1996. Oviposition site choice and life history evolution. American Zoologist 36, 205-215.

Seymour, R.S., Kennett, R., Christian, K., 1997. Osmotic balance in the eggs of the turtle Chelodina rugosa during developmental arrest under water. Physiological Zoology 70, 301-306.

Spencer, R.J., 2002. Experimentally testing nest site selection: fitness trade-offs and predation risk in turtles. Ecology 83, 2136-2144.

Spotila, J.R., Zimmerman, L.C., Binckley, C.A., Grumbles, J.S., Rostal, D.C., List, A.J., Beyer, E.C., Philips, K.M., Kemp, S.J., 1994. Effects of incubation conditions on sex determination, hatching success, and growth of hatchling desert tortoises, Gopherus agassizii. Herpetological Monographs 8, 103-116.

Thompson, M.B., 1993. Oxygen-consumption and energetics of development in eggs of the leatherback turtle, Dermochelys coriacea. Comparative Biochemistry and Physiology A - Physiology 104, 449-453.

Watson, J.W., Epperly, S.P., Shah, A.K., Foster, D.G., 2005. Fishing methods to reduce sea turtle mortality associated with pelagic longlines. Canadian Journal of Fisheries and Aquatic Sciences 6, 965-981.

Webb, G.J.W., Messel, H., Magnussen, W.E., 1977. The nesting of Crocodylus porosus in Arnhem Land, northern Australia. Copeia, 238-249.

Whitmore, C.P., Dutton, P.H., 1985. Infertility, embryonic mortality and nest-site selection in leatherback and green sea turtles in Suriname. Biological Conservation 34, 251-272.

Wood, D.W., Bjorndal, K.A., 2000. Relation of temperature, moisture, salinity, and slope to nest site selection in loggerhead sea turtles. Copeia, 119-128. 